\title{
The Natural Tourism Development Model and Its Contribution to Local Community Economy at Peliatan Village, Ubud Bali
}

\author{
Udayana University \\ Denpasar \\ Udayana University \\ Denpasar
}

Ni Putu Ratna Sari ${ }^{1}$, Anak Agung Putri Sri ${ }^{2}$

\begin{abstract}
The research is located at Peliatan Village Ubud Bali. The purpose of this research is 1) to identify the potential of natural tourism at Peliatan Village Ubud, 2) to examine contribution of the development of natural tourism to the local community's economy at Peliatan Village Ubud, 3) to formulate the natural tourism development model at Peliatan Village Ubud.

The results showed that the potentials of natual tourism at Peliatan Village are a natural panorama, river, springs, rice fields, flora and fauna. Natural tourism activities that can be developed are tracking, cycling, rural tourism, outbound tours, camping tours, natural education tours, flora and fauna observation tours. The contribution of natural tourism to the local community economy is to directly open new jobs for the community, such as tour guides, ticket guards, parking attendants, Balinese food and beverages sellers, business men on food stalls / restaurants, lodging, making souvenirs, Balinese food, making camping, other outbound activities. It is directly improving the ability of the community to save, sending children to a higher level education.

It indirectly could increase income of local community, attract investors to build hotels and inns. Natural tourism development model at Peliatan Village is a SO Strategy: developing new tourist attraction, cooperating with Balinese investors from outside the area to develop natural tourism attraction, penetrating foreign tourist market on special interest in nature, developing potential market of foreign tourists being interested in natural tourism, establishing cooperation with travel agent / wholesaler of special interest tourist market, developing tourism event, and developing micro business.

WO Strategy: improving the quality of the natural environment by maintaining the cleanliness of the natural environment, training natural tourist guides, providing broader and more interesting natural tourism information, designing exciting natural tourism packages, developing private-community partnerships, providing and mapping potential diversity data at tourist destination. Strategy ST: reforestating, controlling erosion, analyzing the influence of the behavior of number of tourist, waste generated, developing plans, protecting regional agreement, cooperating with tourism actors and stakeholders, ensuring the security of Peliatan Village.

WT Strategy: counseling, formulating, and implementing Code of Conduct (COC) product of marketed natural attraction, strengthening organization or association of entrepreneurs and tourism professionals, establishing and / or strengthening of organization of village organization to prevent environmental degradation, coaching community on green tourism, and doing research on natural tourism and its impact on local communities.
\end{abstract}




\section{INTRODUCTION}

Peliatan Village has a very beautiful tracking path, springs that can be used as tracking path for tourists, and rice fields that can be a place for a tour. This is done to reduce tourist saturation with monotonous tourism products, so that natural tourism is very promising to create a new source of income for local communities in Peliatan Village. Because of this phenomenon, research about natural tourism development model and its contribution to local community in Peliatan Village is important to do. The purpose of this research is 1) To identify the potencial of natural tourism in Peliatan Ubud, 2) developing natural tourism on the local community's economy in Peliatan Village Ubud, 3) Formulating natural tourism development model in Peliatan Village Ubud

\section{2. RESEACRH METHOD}

The research is located in Peliatan Village, Ubud District Gianyar Regency Bali. It is quite close to the cultural center of Ubud. It can be reached approximately 45 minutes from the city of Denpasar. Qualitative and quantitative data were used with primary and secondary data sources. Samples taken in a random way, 50 people who visit the village and 100 people from local community respondents. Informants were those of local community and tourism agents in Peliatan Village, and Head of the village.

In this study, data were collected by techniques of observation, interview and questionnaire distribution. Data were analyzed with Likert scale to know the attitude of tourists and local people to the development of natural tourism in Peliatan Village, from 1 to 4 . The use of scale 1 4 for each respondent answer was then divided into four categories namely:

a. Strongly Agree (SA) given a score of 4

b. Agree (A) is given a score of 3

c. Disagree (D) is given a score of 2

d. Strongly Disagree (SD) is given a score of 1

The Result of data analysis was presented either formally (in tabular form) or informally (in narrative form). The SWOT analysis by using SWOT diagrams and matrices produced natural tourism development model and its contribution to local community economy in Peliatan Village.

\section{3. DISCUSSION}

Characteristics of tourists who provided assessment of Their attitude towards the natural tourism development in Peliatan Village, are as follows:

\section{A. $\operatorname{Sex}$}

The number of tourists visiting Peliatan Village surveyed by sex was $40 \%$ male and $60 \%$ female, so that based on the data collected it can be concluded that most of the tourists who visited Peliatan Village were female dominantly coming from America, England, Australia, Sweden, etc.

B. Age

The analysis of the number of tourists visiting Peliatan Village surveyed by age classification was $<20$ years old was 2\%, 20-29 years old was 22\%, 30-39 years old was $42 \%, 40-49$ years old was $28 \%, 50-59$ years old was $6 \%$ th and no tourists surveyed over the age of 60 years. It can be concluded that most tourists who visited Peliatan Village aged between 30-39 years. this is because most of the tourists want to find a quiet atmosphere, away from the noise and beautiful nature is supported by a unique culture. Peliatan Village then became their target.

\section{Education}

Based on surveys conducted, the types of education of tourist coming to Peliatan Village were: $62 \%$ college education (Bachelor, and Master Degree), 36\% High School (HS), and $2 \%$ Junior School. It can be concluded that the recent education of tourists visiting Peliatan Village was dominantly in higher education.

\section{Work}

Based on surveys conducted, the analysis of the number of tourists visiting Peliatan Village based on the type of work was: $20 \%$ students, $52 \%$ entrepreneurs, $2 \%$ government employees, $18 \%$ teachers / lecturers, and $8 \%$ work in the sector plantations (Farmers). Based on the information obtained it can be concluded that the dominant tourists who came to Peliatan Village work on entrepreneurship sector (Business).

\section{E. Frequency of visit}

Based on surveys conducted, the analysis of the number of tourists visiting Peliatan Village based on visiting frequency was: $36 \%$ visited only 1 time, $54 \%$ visited twice, and $10 \%$ had visited more than 2 times. So based on the information obtained it can be concluded that the dominant frequency of tourists who came to Peliatan Village was only 2 times. so it is expected to village government officials and villagers to think together how to attract tourists to be able to increase the frequency (number) of their visit in Peliatan Village

\section{F. Length of visit}

Based on the survey conducted, the analysis of the number of tourists visiting Peliatan Village based on the length of visit was: $16 \%$ only visited 1-2 days, $56 \%$ visited for 3-4 days, $28 \%$ for 4-7 days. So based on the information obtained it can be concluded that the dominant frequency of tourists who come to Peliatan Village only visit for 3-4 days. so it is expected that village government officials and villagers to think together how to attract tourists to be able to increase the length of their visit in Peliatan Village. perhaps by providing entertainment packages, Tour and Traveling, etc. 


\section{G. Reason to Visit Peliatan Village}

Based on interviews conducted on tourists who came in Peliatan Village, tourists responses were because of some reasons: the natural tourism reason was equal to $98 \%$ and the cultural tourism by $2 \%$. So dominant tourists who came to Peliatan Village were looking for a tranquility, supported by rural nature (tracking path through beji in banjar pande), paddy fields, and away from urban hustle bustle. Besides that in Peliatan Village precisely in banjar Tebesaya there is a place of Yoga (her name: Yoga Barn), one of tourist attraction to visit Peliatan Village.

\section{H. Types of Natural Tourism Suitable to Be Developed}

Based on interviews conducted on the tourists who came in Peliatan Village, their response on the suitable kind of natural tourism developed in Peliatan Village included: Tracking was $31 \%$, Cycling was $39 \%$, natural education tour was $1 \%$, Nature-based rural tourism was $19 \%$, and ATV tours by $5 \%$. So it can be concluded: that natural tourism that needs to be developed in Peliatan Village is cycling and tracking tour. This is supported by the track for tracking and cycling with views and social activities of people around the track. But the track needs to be rearranged in order to be optimally developed.

\section{Types of Natural Tourism Purchased}

Based on the interview conducted to the tourists coming to Peliatan village, their response to the types of natural tourism that has been purchased: tracking was $31 \%$, Camping was $8 \%$, cycling was $21 \%$, natural education tour was $8 \%$, natural-based village tour was $6 \%$, Natural Adventure was $11 \%$ and ATV tour was $15 \%$. So it can be concluded that natural tourism that were mostly purchased was tracking so that they expected that there must be natural tracking tours developed in Peliatan Village.

\section{J. Motivation of Visitor}

Motivation of visitors to Peliatan Village: recreation was $88 \%$, physical and mental refreshment, experience, knowledge, and skill was $4 \%$, and exploring tourist objects was $9 \%$. Based on the response given, the community should then cooperate with government officials in order to manage areas having potentials to be natural tourist destination in Peliatan village, so that the number of visiting tourist can be increased next year.

\section{K. Reason to Visit}

Reasons of tourists visiting Peliatan village: $93 \%$ was because of beautiful views and fresh air and $7 \%$ was because of harmoniously social life.

\section{THE PERCEPTION OF TOURISTS TOWARDS THE NATURAL TOURISM DEVELOPMENT IN PELIATAN VILLAGE}

The results showed that the perception of tourists to natural tourism as follows:

\section{A. The Perception of Tourists to the Potential of Nature}

a. Natural Tourism Is Suitably Developed in Location of Peliatan Village

Most of the tourists welcome the development of natural tourism in Peliatan Village. This is seen from the data collected in the survey of $24 \%$ of tourists strongly agreed with the development of natural tourism, and $76 \%$ agreed. Therefore, some of the tourists hoped the cooperation between the government and the community in order to develop natural tourism in Peliatan Village, both in terms of infrastructure improvements, as well as in terms of its promotion.

b. Overlay of rice fields, rivers, flora and fauna can be natural tourism potentials in Peliatan Village

The results showed that tourists who come in Peliatan Village, $8 \%$ strongly agreed if the rice fields, flora and fauna can be naturals potential in Peliatan Village, while $92 \%$ agreed. It was hoped that the community could cooperate with the village officials to re-arrange the natural potentials in Peliatan Village, so that it could become a tourist attraction factor coming to Peliatan Village. In addition there weree also tourists who suggested that there must be a package of natural tourism combined with cultural tourism in Peliatan Village. such as: tracking package along with viewing the rice fields, then seeing the activities of the community in the fields, irrigation system, so that tourists coming to Peliatan Village became more satisfied, because beside refreshing mind, they could also get knowledge about Balinese culture, especially the community tradition in Peliatan Village

\section{B. Tourist Perception on Infrastructure and Tourism Facilities}

a. Public road to Peliatan Village can be easily passed

Based on interviews conducted on tourists who came in Peliatan Village, $8 \%$ was strongly agreed if the public road to Peliatan Village can be passed easily, while the rest of $92 \%$ agreed. However, many tourists complained that the roads leading to Peliatan Village, especially in the juction of Banjar Kalah to Peliatan and pengosekan, and in Arjuna Statue in the junction of Banjar Ambengan there was frequently a traffic jam so that it can disrupt the access of tourists. Fortunately, there was no complain about the road quality

b. Public transport to Peliatan Village

In terms of public transport availability, tourists gave responses of $10 \%$ strongly agree, $86 \%$ agree as well as $8 \%$ disagree. Unfortunately tourists complained about freeland taxi operating around Peliatan Village, no standardization of taxi costs, so the drivers were free to offer the price to tourists. Besides the decline of public transportation such as bemo, mikrolet also become a complaint of tourists who come to Peliatan Village.

c. Peliatan Village provides restaurant and restaurant facilities

With the increase of tourist visit to Peliatan Village, both natural and cultural tourism increased community initiative 
in Peliatan Village to make restaurant and food stalls. This can be seen in Banjar Tebesaya, as well as in Peliatan Village square. Restaurants and food stalls increased in number so that it can support tourism in Peliatan Village, the tourists can choose the variety of food, both Balinese foods and Indonesian foods and western foods. In this case, $84 \%$ of tourists agreed.

d. Peliatan Village provides facilities available place to stay.

With the increasing of tourist visit to Peliatan Village, both natural tourism and cultural tourism, increased community initiative in Peliatan Village to make accommodation effort such as hotel, villa, Guest House etc. It can be seen in Banjar Tebesaya, accommodation business increased in number, so that people no longer got confused in looking for temporary places to stay during their tour in Peliatan Village. It was $76 \%$ agreed to this

Peliatan Village provides facilities to carry out worship for visitors

Most of the tourists, it was $72 \%$, agreed to this, that the hotel has facilitated them to carry out the worship, but some got complaint that there were no other places of worship in Peliatan Village, except for the temple, so that tourists got a bit difficult to pray. They also proposed to make a special place for tourists to pray like Puja Mandala in Nusa Dua.

Peliatan Village provides parking facilities for visitors' vehicles

Based on the results of research that has been done, it was found that $6 \%$ strongly agreed, $76 \%$ agreed and $18 \%$ disagreed to providing parking facilities. Tourists were still disappointed in the arrangement of parking area in Peliatan Village. The lack of parking lots available might cause guests to park car carelessly. This might cause traffic jam then. This needs to be coped with by the village government. e. Service to Tourists

People are friendly to tourists visiting Peliatan Village. Tourists in the amount of $78 \%$ agreed to local communities in Peliatan Village who are very friendly. They even keep the tradition and ancestral culture. This became one of the attractions of tourists to visit Peliatan Village.

People always provide the needs of tourists. According to the survey conducted, it was found that $82 \%$ of tourists think that people have been able to meet their needs during the trip to Peliatan Village, while the rest of $18 \%$ still responded that the community has not been able to meet the needs of tourists during a trip in Peliatan Village.

f. People are willing to be a guide

$84 \%$ of tourists give very good appreciation to the people of Peliatan Village, because they think Peliatan villagers are very helpful to them as guides if they got problems of destination, guides were able to tell the history of the tourist attractions.

g. People participate in maintaining security in the area of tourism for the convenience of the visitors

It was found that $90 \%$ of tourists think that people have participated in keeping the tourist object by involving the village security unit (Pecalang) in some tourist objects. However, they hope for the cooperation between security of tourist destination and the pecalang in maintaining the security and comfort of visitors to the object and destination.

\section{Perceptions of public attitudes towards the Natural Tourism Development in Peliatan Village Ubud}

Peliatan Village community agreed more than 50\% towards the natural tourism development in Peliatan Village. The results showed that:

a. In the promotion aspect, $76 \%$ of people came to introduce Peliatan Village to tourists. 59\% of the community introduced Peliatan Village during the exhibition. In promoting Peliatan Village, $67 \%$ of people agreed to the cooperation between the government and the community. $68 \%$ of people thought that promotion should be done by utilizing other meetings. Peliatan Village has been introduced in the event of exhibition, such as: PORDES Exhibition which is annually held People gave response that there has been cooperation between government, both at village and regional level with society in terms of promoting Peliatan Village through travel agents, village web and others. Promotions are usually discussed in Village meetings. Peliatan Village development, both in terms of life, social economy, and about the development of tourism were also taken into account.

b. On the economic aspect it was found that the natural tourism development would be able to contribute to the family economy. In detail the results of the study showed that $79 \%$ of people thought that there was no problem to live along with the development of tourism. $84 \%$ thought that the natural tourism could increase the family income. $78 \%$ thought that it could meet the daily needs of the community. $82 \%$ thought that it could get a permanent job. $88 \%$ could send to higher education

c. On the aspect of employment, people of Peliatan Village agreed that the development of natural tourism could increase employment for them. Results of the study showed that the development of natural tourism opens new jobs for them. $81 \%$ thought that they would be tour guides, $82 \%$ thought that it would add local income either in the form of taxes so as to increase development and open employment. $88 \%$ said it would open opportunities for them to open dinning / restaurant business. $83 \%$ said it would give them an opportunity to open businesses of accommodation. $84 \%$ said it would create job opportunities. $87 \%$ said it would increase souvenirs, create job opportunities in making Balinese food business, create jobs in making camping business, other outbond $84 \%$, creating jobs of making business of selling natural tourism packages $84 \%$.

On the aspect of development of economic activity, people also agreed. The results showed that the development of natural tourism in Peliatan Village increased 
the wheels of the people's economy in which $85 \%$ agreed and only $1 \%$ disagreed. The development of natural tourism could attract investors to build hotels and inns were also obtained $83 \%$ agreed and only $6 \%$ disagreed. The development of natural tourism could increase people's income so that people's ability to save increases $86 \%$ and $6 \%$ disagreed and totally disagreed $2 \%$. This shows that the development of natural tourism could drive the economy of local communities.

\section{THE POTENTIAL OF NATURAL TOURISM IN PELIATAN VILLAGE UBUD}

Activities that can be developed to support Natural tourism in Peliatan Village:

\section{A. Tracking Tour}

Natural panorama of Peliatan Village can be enjoyed by tourists who do tracking. Tourists can explore the path along the village, see the river, rice fields, water springs, see the flora and fauna. They could even stop over at the local residents to see such cultural activities as: sculpting, dancing, beating gamelan, painting, making crafts and so forth. Tracking path in Peliatan Village are:

a. The southern boundary of Peliatan Village (north of Pura Tirta) - subak soca rice field - beji springs - rice field residents in banjar Kalah - banjar Kalah. It takes about 2 hours

b. From bale banjar Teges Kawan Yangloni to the northen part to sees natural utilization for rural villages - rice field - Bedugul temple of Subak Santian - to the west to bale banjar pande - cross the bridge - Selatan Panti Pande temple- to the south to Puri Agung Peliatan. It takes $2-3$ hours.

c. The office of Peliatan Village to the north - bale banjar truna to the west - up to Belong - to the west through the making of typical betutu ayam - belong springs - tebesaya kelod - to the north north to banjar tebesaya residence to the north - up to Pura Dalem Puri. It takes 2 -3 hours

d. From Puri Peliatan to the north - up to banjar pande- to the eastern part of the pande temple - rice field - bedugul temple of subak santian to the north - Gunung sari street Pura Gunung Sari - Pura Alas Arum. It takes 2 - 3 hours

e. From Puri Peliatan to the north - up to the banjar Pandeto the eastern part to Panti Pande temple - rice fields Bedugul temple of subak santian to the north - Gunung Sari street - to the west - intersection of Ubud Tegallalang - to the west to Pura Dalem Puri. It takes 2 3 hours.

\section{B. Flora and Fauna Sightseeing Tour}

Geographically Peliatan Village is located in 8036'30 "LS and 1150 21'05" BT and $350 \mathrm{~m}$ above sea level. Topographic condition of Peliatan Village resources in the form of plain land of: rice field: 246 ha; moor: 103,76 ha; yard: 25,76 ha, settlement: 78,56 ha, grave: 2,90 ha and for other purpose 36.02 ha. This can be used as tourist destination and objects of the flora and fauna in Peliatan Village. This type of tour can be more specifically the joy of flora and fauna of different types of medicine plants, local vegetables, such as paku vegetable that can be found in rice fields, kelor vegetables, katuk vegetables, keladi vegetables and others, plants for ceremony and offering in Bali, spices ingredients of Balinese cuisine. A butterfly tour and firefly tour could also be developed accordingly

\section{Natural Education Tour}

Some tourism activities associated with education could be developed in Peliatan Village Ubud. Some of them: teaching domestic and foreign tourists how to plant rice, plough the rice fields using traditional tools. So tourists could learn while travel in.

\section{Outbound Tour}

The utilization of moor in Peliatan Village might lead to an outbound games tour packages, such as flying fox, ATV and so forth

\section{E. Tour of the Village}

Tourism activities that can be developed in Peliatan Village is a rural tour. This type of tour can be done by collaborating tracking activities, flora and fauna sightseeing, education and outbound tours. Rural Tourism can be enjoyed by tourists who want to observe and learn how to live the local community. They are invited to the village tour to know the types of vegetables, ingredients of Balinese cuisine, types of livestock, so at this stage tourists are invited to learn cooking Bali cuisine directly in traditional Balinese kitchen. Tourists can be shown how to make a typical chicken betutu of Peliatan Village, vegetable urab, lawar Bali, chicken tum and so forth.

\section{F. Eco-Cycling}

Tourists are invited to explore pollution-free villages using bicycles, see the natural beauty along the way, see the life of the villagers. Finally, tourists are treated to traditional food and entertained with traditional Balinese dance. Before going home, foreign tourists are given the opportunity to buy handicrafts, do cycling, see the life of villagers with fresh air into memories

\section{G. Camping}

This tour can be done in the courtyard area of Gunung Sari temple, banjar Ambengan Peliatan Village Ubud. In this tourist activity tourists can perform activities such as enjoying the atmosphere of the night under the sky.

VI. Contribution of Natural Tourism Development to Local COMMUNity ECONOMY IN PELIATAN VILlage, Ubud

The development of natura ltourism in Peliatan Village would certainly be able to run well if there is support from all sectors, companies related to tourism services, suppliers, marketing intermediaries, consumers, competitors, and 
society. All of these components are very supportive of a destination to attract tourists. Some of the things that need to be analyzed in the marketing environment are:

\section{Company}

There are several industrial companies in the Peliatan Village. Most of them are: the commodity-making industry of religious ceremonies, food stalls, workshops and shops. While the industry engaged in tourism consists of Art Studio both dance art, art tabuh, and painting, Homestay, Hotel, guest house, Restaurant, coffe bar, and cafe. There are at least 100 hotels, homestays, guest houses and inns with an average price of Rp. 180,000 per night for non AC, and Rp.250,000 per night for AC facilities. There are 50 restaurants, food stalls and cafes. Besides, the tourist attractions to visit in Peliatan Village are a legong and kecak dances, customs, and religious ceremonies. Today, however, tourists are not so much interested in watching the dance due to the unfair price and PATREM (permit) prevailing from Distibia Regency.

\section{Supplier}

Most of the suppliers to hotels, villas, homestays, restaurants, cafes come from outside Peliatan Village area. Only few of local people Peliatan Village became suppliers to hotels, villas, homestays, restaurants, and cafes located in Peliatan Village area. However, most of local people tend to be supplier to handicrafts sold in artshop.

3. Marketing intermediator: the marketing of tourism industry in Peliatan Village, can be conducted directly (personally) between industry owner and consumer under coordination of village officials / village administrators. It can be done by distributing brochures to travel agents, as well as through websites on the internet.

\section{Consumer}

The visitors of Peliatan Village come from foreign tourists such as China, America, Australia, Japan, Korea and others. The dominant tourists come from China. They are interested in seeing typical Balinese dances such as kecak and legong dances. Besides, there are also domestic tourists, who come from the island of Java, Kalimantan.

\section{Competitor:}

There are a lot of competitiors coming from Ubud village, which is very closed to Peliatan Village, Petulu village, Mas village, Tegalalang village, and Pejeng village. Ubud village has Ubud market serving and offering various kinds of art goods and a number of supporting tourism infrastructures, such as hotels, restaurants, homestays, cafes and others, Besides, Ubud has frequently performed kecak dance and legong dance, making it the most serious threat to Peliatan Village, although it sometimes does not match with PATREM issued by DISTIBIA regency. Meanwhile, Petulu Village is famous for its eco-like birdwatching and kokokan. Mas Village is famous for its unique sculptures. Tegallalang Village has beautiful natural scenery and as a handicraft supplier as well. Many villas are built in Pejeng village and it has the potential of natural tourism very much. Many tourists often do cycling while enjoying the beauty of rice fields.

\section{Public}

Until now Peliatan villagers are still lacking in getting empowerment and coaching guidance from the village government, district and provincial governments, so it is expected the people can have a coaching, especially in handling the problems of tourism, so it can support the tourism life in Peliatan Village area. Peliatan Village people are always involved in decision making concerning tourism, in order to avoid misunderstanding and unconformity between the village government and the community. Each will have a development or any plan related to the village, village officials always communicate to the community through village meetings. In the house regulation of the village it is stipulated that there are some rules about the development of tourism in Peliatan Village, where the development of tourism in Peliatan Village should be in line with Tri Hita Karana, and not threaten the harmony of nature and society, and the prohibition to the community to traded customary land (PKD) as well as village wasteland (AYDS).

All of the above components can support the activities of natural tourism that will be developed in Peliatan Village. Local people not only as the owner of homestay, the owner of arshop, but also can develop natural tourism products as an attraction to come to visit Peliatan Village.

The contribution of natural tourism to the economy of local communities is as follows:

a. The natural tourism activities must be directly supported by supporting facilities such as accommodation facilities, transportation, restaurants or food stalls.

b. The development of natural tourism opens new jobs for the community, such as tour guide, ticket guard, parking attendant, selling typical Balinese food and drinks and so forth. So that the income earned by the local community can be useful for daily life as part of the community that is in the tourism destinations.

c. The development of natural tourism can give the opportunity to open a food stall/ restaurant, to give the opportunity to open a businesses of lodging / accommodation, souvenirs making, Balinese foods, camping, other outbound, selling natural tour packages.

d. The development of natural tourism in Peliatan Village drives the wheels of the people's economy. It can attract investors to build hotels and inns.

e. The development of natural tourism can increase people's ability to save money. This shows that it can drive the local people's economy.

$\mathrm{f}$. The development of natural tourism can meet the daily needs and can send their children to the higher level of education.

g. The development of natural tourism can make people to have no problem in earning and living 
h. Natural tourism can increase family income, meet the daily needs, result in getting a permanent job, send their family members to a higher education.

Indirectly:

a. The tourism activities can increase the local income of the village. It can improve the development and open new job vacancies. People are commiited to obey "Tri Hita Karana" conceptions: maintaining good relationship with God, environment and between humans. If three are no harmony, there is no balance then. Besides, people believe that even though tourism has been growing fast, they would not forget the tradition and customs that have been inherited by our ancestors. This is unvaluable heritage.

The development of natural tourism can attract investors to build hotels and inns. They think that investors can accelerate the development of tourism in Peliatan Village, but they are also restless if investors keep buying and making use of the land in Peliatan Village indiscriminately that can disrupt the social life of society and environment in Peliatan Village. Meanwhile, there are people being disagreed with the intervention of investors in the development of natural tourism in Peliatan Village. 


\begin{tabular}{|c|c|c|}
\hline $\begin{array}{l}\text { INTERNAL } \\
\text { EKSTERNAL }\end{array}$ & $\begin{array}{l}\text { Strenght } \\
\text { 1. Location Peliatan Village } \\
\text { adjacent to Ubud Art Center } \\
\text { 2. Have the natural potential } \\
\text { of the paddy fields, natural } \\
\text { scenery, flora and fauna, the } \\
\text { river to be developed into } \\
\text { natural tourism } \\
\text { 3. Tourists love trekking, } \\
\text { nature-based rural tourism, } \\
\text { cycling tours } \\
\text { 4. Accessibility is very good } \\
\text { 5. Public transport available } \\
\text { 6. Spacious parking lot in } \\
\text { the square } \\
\text { 7. There are facilities and } \\
\text { infrastructures supporting } \\
\text { nature tourism that is } \\
\text { accommodation, restaurant, } \\
\text { health facility } \\
\text { 8. Community support for } \\
\text { the development of nature } \\
\text { tourism }\end{array}$ & $\begin{array}{l}\text { Weakness } \\
\text { 1. 1. People have not } \\
\text { seen natural tourism } \\
\text { opportunities in } \\
\text { Peliatan Village } \\
\text { 2. 2. SDM "guide" } \\
\text { nature tour is still } \\
\text { minimal } \\
\text { 3. 3. Cleanliness is less } \\
\text { awake. } \\
\text { 4. 4. The beauty of } \\
\text { telebakan less awake } \\
\text { 5. 5. Concretization is } \\
\text { increasing } \\
\text { 6. Understanding } \\
\text { about the } \\
\text { environment is still } \\
\text { lacking. } \\
\text { 7. RTHD (Green } \\
\text { Village Open Space) } \\
\text { is getting smaller. } \\
\text { 8. } 8 \text { The character of } \\
\text { the village shifts } \\
\text { along the main road } \\
\text { of the village: } \\
\text { formerly the } \\
\text { dominant Bali view, } \\
\text { now the dominant } \\
\text { "external cultural" } \\
\text { view } \\
\text { 9. 9. Information of } \\
\text { tourism attractions is } \\
\text { minimal. } \\
\text { 10. 10. Purchase of land } \\
\text { in large scale, among } \\
\text { others, for tourism } \\
\text { accommodation } \\
\text { facilities } \\
\text { 11. Potential data The } \\
\text { diversity of flora-fauna } \\
\text { has not been recorded }\end{array}$ \\
\hline $\begin{array}{l}\text { Opportunities } \\
\text { a. Nature lovers } \\
\text { b. } \\
\text { Diversification } \\
\text { of tourism } \\
\text { products, among } \\
\text { others: trekking, } \\
\text { camping, nature- } \\
\text { based rural } \\
\text { tourism, cycling, } \\
\text { nature-based } \\
\text { education } \\
\text { tourism } \\
\text { c. cooperation } \\
\text { with travel-travel } \\
\text { area outside } \\
\text { d. Economic } \\
\text { improvement of } \\
\text { Peliatan Village } \\
\text { communit }\end{array}$ & $\begin{array}{l}\text { SO Strategy } \\
\text { 1. Develop a unique natural } \\
\text { attractions / unique } \\
\text { attractions. } \\
\text { 2. Cooperate with Balinese } \\
\text { investors from outside the } \\
\text { region to develop natural } \\
\text { tourism attractions } \\
\text { 3. Penetration of foreign } \\
\text { tourist market with focus on } \\
\text { special interest tourists that } \\
\text { is nature } \\
4 \text {. Development of foreign } \\
\text { tourists market potential that } \\
\text { is interested in nature } \\
\text { tourism } \\
\text { 5. Establish cooperation with } \\
\text { travel agents / wholesalers } \\
\text { who have a market of special } \\
\text { interest tourists } \\
\text { 6. Development of tourism } \\
\text { events by involving local }\end{array}$ & $\begin{array}{l}\text { WO Strategy } \\
\text { 1. Improving the quality } \\
\text { of the natural } \\
\text { environment by } \\
\text { maintaining the } \\
\text { cleanliness of the natural } \\
\text { environment } \\
\text { 2. Train competent } \\
\text { natural guides } \\
\text { 3. Provide information of } \\
\text { nature tourism more } \\
\text { widely and interesting } \\
\text { 4. Compose a package of } \\
\text { natural tour packages } \\
\text { more interesting } \\
\text { 5. Develop a private- } \\
\text { community partnership } \\
\text { pattern in the provision } \\
\text { of tourism supporting } \\
\text { natural tourism facilities. } \\
6 . \quad \text { Provision and }\end{array}$ \\
\hline
\end{tabular}

\begin{tabular}{|c|c|c|}
\hline & $\begin{array}{l}\text { communities as organizers } \\
\text { 7. Development of micro } \\
\text { business for local }\end{array}$ & $\begin{array}{l}\text { mapping of potential data } \\
\text { on diversity in DTW. }\end{array}$ \\
\hline $\begin{array}{l}\text { Threat } \\
\text { a. Pengaruh } \\
\text { alam : banjir, } \\
\text { tanah longsor } \\
\text { b. Pengaruh } \\
\text { perilaku } \\
\text { wisatawan } \\
\text { yang tidak } \\
\text { ramah } \\
\text { lingkungan } \\
\text { c. Pencemaran } \\
\text { lingkungan } \\
\text { alam } \\
\text { masyarakat } \\
\text { sendiri } \\
\text { d. Banyaknya } \\
\text { saingan } \\
\text { destinasi } \\
\text { e. sebagai } \\
\text { pesaing yang } \\
\text { bisa } \\
\text { mengembang } \\
\text { kan } \\
\text { pariwisata } \\
\text { alam } \\
\text { f. Adanya } \\
\text { kebijakan } \\
\text { kebijakan } \\
\text { desa yang } \\
\text { merugikan } \\
\text { lingkungan } \\
\text { alam } \\
\text { g. Masuknya } \\
\text { investor asing } \\
\text { yang tidak } \\
\text { memperhatika } \\
\text { n lingkungan } \\
\text { alam }\end{array}$ & 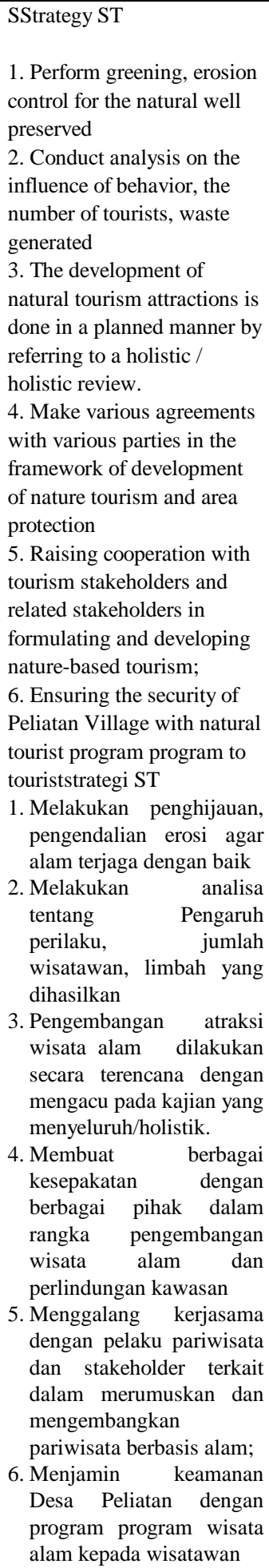 & $\begin{array}{l}\text { StrategWT Strategy } \\
\text { 1. Conducting tourism } \\
\text { counseling to provide an } \\
\text { understanding of the } \\
\text { community about nature } \\
\text { tourism. } \\
\text { 2. Formulating and } \\
\text { implementing code of } \\
\text { conduct (CoC) for each } \\
\text { product of nature tourism } \\
\text { attraction that is } \\
\text { marketed } \\
\text { 3. Strengthening of } \\
\text { employers' organizations } \\
\text { or associations and } \\
\text { tourism professionals, } \\
\text { such as Gahawisri, } \\
\text { PHRI, ASITA, HPI, etc. } \\
\text { 4. Establishment and / or } \\
\text { strengthening of village } \\
\text { organizations to prevent } \\
\text { environmental } \\
\text { degradation. } \\
\text { 5. Standardization of } \\
\text { human resources capacity } \\
\text { of tourism through } \\
\text { certification for tourism } \\
\text { sector workers. } \\
\text { 6. Community } \\
\text { development to better } \\
\text { understand } \\
\text { environmentally friendly } \\
\text { tourism for tourism } \\
\text { sustainability. } \\
\text { 7. Conduct research on } \\
\text { nature tourism and its } \\
\text { impact on local } \\
\text { communitiesi WT }\end{array}$ \\
\hline
\end{tabular}




\begin{tabular}{|c|l|}
\hline SO Strategy & Program \\
\hline $\begin{array}{c}\text { 1. Developing new unique } \\
\text { tourist attractions }\end{array}$ & $\begin{array}{l}\text { developing unique tourist } \\
\text { attractions }\end{array}$ \\
\hline $\begin{array}{c}\text { 2. Cooperating with Bali } \\
\text { investors of outside the } \\
\text { areas to develop natural } \\
\text { tourist attractions }\end{array}$ & $\begin{array}{l}\text { developimng new tourist } \\
\text { attractions in collaboration with } \\
\text { local investors }\end{array}$ \\
\hline $\begin{array}{c}\text { 3. Penetrasi pasar } \\
\text { wisatawan mancanegara } \\
\text { dengan fokus pada } \\
\text { wisatawan minat khusus } \\
\text { yaitu alam }\end{array}$ & $\begin{array}{l}\text { Melakukan promosi ke wisatawan } \\
\text { mancanegara yang tertarik pada } \\
\text { wisata alam }\end{array}$ \\
\hline $\begin{array}{c}\text { 4. Developing tourist market } \\
\text { potentials for foreign } \\
\text { tourists who are interested } \\
\text { in natural tourism }\end{array}$ & $\begin{array}{l}\text { promoting to foreign tourists who } \\
\text { are interested in natural tourism }\end{array}$ \\
\hline $\begin{array}{c}\text { 5. Cooperating with travel } \\
\text { agencies of specific interest } \\
\text { of market segments }\end{array}$ & $\begin{array}{l}\text { cooperating with travel agencies } \\
\text { of specific interest of market } \\
\text { segments (natural tourism) }\end{array}$ \\
\hline $\begin{array}{c}\text { 6. Developing tourist events } \\
\text { of which performer is local } \\
\text { people }\end{array}$ & $\begin{array}{l}\text { making tourist events in Peliatan } \\
\text { Village }\end{array}$ \\
\hline $\begin{array}{c}\text { 7. Developing micro } \\
\text { business on tourism for } \\
\text { local people }\end{array}$ & $\begin{array}{l}\text { helping local people to open } \\
\text { business on tourism of small scale }\end{array}$ \\
\hline
\end{tabular}

\begin{tabular}{|c|c|}
\hline WO Strategy & Program \\
\hline $\begin{array}{l}\text { 1. Improving the natural } \\
\text { environment quality by } \\
\text { keeping the cleanliness } \\
\text { of the environment }\end{array}$ & $\begin{array}{l}\text { doing counseling regarding nturL } \\
\text { ENVIRONMET IN Peliatan } \\
\text { Village }\end{array}$ \\
\hline $\begin{array}{l}\text { 2. Training tourist guides } \\
\text { to be a competent ones }\end{array}$ & training tourist guides \\
\hline $\begin{array}{l}\text { 3. Providing information } \\
\text { about a wider and more } \\
\text { attractive renatural } \\
\text { tourism }\end{array}$ & $\begin{array}{l}\text { making information system of } \\
\text { tourism consisting of ourist } \\
\text { natural attractions through printed } \\
\text { and electronic media }\end{array}$ \\
\hline $\begin{array}{lr}\text { 4. Designing a } & \text { more } \\
\text { interesting } & \text { natural } \\
\text { tourism packages } & \end{array}$ & $\begin{array}{l}\text { Making unique and interesting } \\
\text { natural tourism packages }\end{array}$ \\
\hline $\begin{array}{lr}\text { 5. Developing } & \text { cooperating } \\
\text { system in } & \text { providing } \\
\text { supporting } & \text { tourism } \\
\text { infrastructures } & \\
\end{array}$ & $\begin{array}{l}\text { developing joint-venture model, } \\
\text { local people shares }\end{array}$ \\
\hline $\begin{array}{l}\text { 6. Providing and mapping } \\
\text { various potential data in } \\
\text { tourist destinations }\end{array}$ & \begin{tabular}{lrr} 
doing & research & through \\
educational & \multicolumn{2}{c}{ institution } \\
document & various & natural \\
potentials & &
\end{tabular} \\
\hline
\end{tabular}

\begin{tabular}{|c|l|}
\hline ST Strategy & Program \\
\hline $\begin{array}{c}\text { 1. Doing reboitation, erosion } \\
\text { control, in order that } \\
\text { nature can be well } \\
\text { maintained }\end{array}$ & $\begin{array}{l}\text { doing activity of community } \\
\text { service by reboitation of useful } \\
\text { plants in order to avoid the flood }\end{array}$ \\
\hline $\begin{array}{c}\text { 1. Analyzing the influence of } \\
\text { attitudes of tourist, } \\
\text { number of tourists, and } \\
\text { waste produced }\end{array}$ & $\begin{array}{l}\text { doing researches on the impact of } \\
\text { natural tourism to local people }\end{array}$ \\
\hline $\begin{array}{l}\text { 2. Developing } \\
\text { aomprehensively well- } \\
\text { planned attractions of } \\
\text { natural tourism }\end{array}$ & making natural tourist attractions \\
that be in line with local culture
\end{tabular}

\begin{tabular}{|l|l|}
\hline $\begin{array}{l}\text { parties for natural } \\
\text { rourism development } \\
\text { and areas conservation }\end{array}$ & $\begin{array}{l}\text { regarding conservation of } \\
\text { environmnt }\end{array}$ \\
\hline $\begin{array}{l}\text { 4. Cooperating with the doer } \\
\text { of tourism and } \\
\text { stakeholders regarding } \\
\text { designing and } \\
\text { developing nature-based } \\
\text { tourism }\end{array}$ & $\begin{array}{l}\text { cooperating with stakeholder in } \\
\text { developing natural tourism }\end{array}$ \\
\hline $\begin{array}{l}\text { 5. Keeping the security of } \\
\text { Peliatan village for the } \\
\text { sake of natural tourism }\end{array}$ & making Code Of Conduct \\
\end{tabular}

\section{CONCLUSION}

1. The potential of natural tourism in Peliatan Village is the natural panorama, River, water spring, rice terrace field, Flora and fauna. Natural tourism activities that can be developed in the Peliatan Village are tracking, cycling, rural tourism, outbound tours, camping tours, natural education tours, sightseeing tours of flora and fauna

2. The contribution of natural tourism to the economy of local communities is:

The direct development of natural tourism opens new jobs for the community such as tour guides, ticket guards, parking attendants, Bali food, beverages, opens opportunities for establishing food stalls / restaurants, giving people the opportunity to open businesses such as accommodation, employment opportunities to create souvenirs, create jobs in making Balinese food-making businesses, create jobs in making camping businesses, outbound others, create jobs such as making businesses selling natural tour packages, increasing the ability of people to save, to increase the revenue of an area to increase the development and can open employment for the surrounding community, the development of natural tourism can attract investors to build hotels and inns.

3. Natural tourism development model in Peliatan Village: SO Strategy: Developing new tourist attractions, especially the unique one; working with Balinese investors from outside the area to develop natural tourism attractions; working with Balinese investors from outside the region to develop natural tourism attractions; Penetrating of foreign tourist market with focus on tourists special interest that is nature; developing potential foreign tourist market that is interested in natural tourism; build cooperation with travel agent / wholesaler which has special interest in tourist market; developing tourism event by involving local community as organizer; developing micro business on tourism for local society.

WO Strategy: Improving the quality of natural environment by maintaining the its cleanliness; train competent natural tourist guides; providing information of natural tourism more widely and attractively; preparing a more attractive natural tourism packages; 
developing private-community partnership patterns in the provision of natural tourism supporting facilities; providing and mapping the potential data on diversity in tourist destination areas.

ST Strategy: Performing reforestation, erosion control for the well preserved nature; conducting analysis on the influence of behavior, the number of tourists, the waste generated; developing the well-planned and holistic study on natural tourist attraction; making various agreements with various parties in the framework of the development of natural tourism and the protection of the area; raising cooperation with tourism actors and related stakeholders in formulating and developing nature-based tourism; ensuring the security of Peliatan Village with natural tourist programs

WT Strategy: Conducting tourism counseling to give understanding to the community about natural tourism; formulating and implementing code of conduct $(\mathrm{CoC})$ for each product of marketed natural attraction; strengthening the organization or association of entrepreneurs and tourism professionals, such as Gahawisri, PHRI, ASITA, HPI, etc.; establishment and / or strengthening the village organizations to prevent environmental degradation; standardizing the human resources capacity through certification for tourism sector workers; developing the community for a better understanding on environmentally friendly tourism sustainability; conducting research on natural tourism and its impact on local communities

\section{ACKNOWLEDGMENT}

A deeply thank is addressed to Udayana University which through LPPM that has given a fund this research, as well as for those who have material and formal help so that this research can be completed in time.

\section{REFERENCES}

